Journal of Food and Nutritional Sciences Research (JFNSR) 2021

Volume 3, Issue 1, Pages 130-143

https://doi.org/10.37512/1100

Open Access - Published by the Kenya Institute of Food Science and Technology

Original Research Article

\title{
Physico-Chemical, Microbiological and Sensory Characteristics of Papaya Pulp-Milk Blends Fermented with a Probiotic Starter Culture
}

1,3 Waweru, D.M., ${ }^{1 *}$ Onyango, A.N., ${ }^{1}$ Okoth, A.E.M., ${ }^{2}$ Rimberia, F.K., ${ }^{3}$ Mathara, J.M. \&

${ }^{1}$ Makokha, A.O.

${ }^{1}$ School of Food and Nutrition Sciences, Jomo Kenyatta University of Agriculture and Technology (JKUAT)

2 Department of Horticulture and Food Security, JKUAT.

${ }^{3}$ Department of Food Science and Technology, Meru University of Science and Technology

Correspondence should be addressed to Arnold Onyango: arnold.onyango@jkuat.ac.ke

Received 7.7.2021, Reviewed 25.10.2021, Accepted 2.11.2021

\begin{abstract}
Yoghurt is a popular fermented milk product across the globe. As consumers become more health conscious, there has been rising interest in probiotic yoghurts, fermented with bacteria that can promote human health, as well as yoghurts containing fruit pieces, juice or pulp, which increase the levels of phytochemicals, dietary fibre and some vitamins in the product. Generally, the fruit products are added only up to about $20 \%$. Here we investigated the physicochemical, sensory and microbial properties of analogous fermented products containing milk, but consisting mainly of papaya fruit pulp. Formulations were made at different ratios ranging from 50-100\% papaya pulp. Yoghurt (with $0 \%$ papaya) was made to serve as the control. Conditions for pasteurization prior to fermentation were optimized for the control of yeasts and molds. The products were fermented with a probiotic culture consisting of Streptococcus thermophilus + Lactobacillus acidophilus + Bifidobacterium spp. Sensory analysis on a 9-point hedonic scale revealed an increase in acceptability of the various attributes with increase in pulp. Formulations containing $80 \%$ to $100 \%$ papaya fruit were found to be most liked and of comparable quality to the control, having scores of $\geq 7$ (ranging from moderately liked to liked very much)) in colour, taste, texture and overall acceptability. Compared to the control, these formulations were found to contain more ascorbic acid, riboflavin, niacin, folic acid, dietary fiber and carbohydrates. The control was however higher in thiamine, protein and fat levels. The products were stable under refrigerated storage $\left(4{ }^{\circ} \mathrm{C}\right)$ for 3 weeks.

In conclusion, we found that papaya pulp fermented with a probiotic starter culture, and containing up to $20 \%$ milk had good sensory acceptability. The health benefits of such products are worthy of further investigations.
\end{abstract}

Key words: Papaya, fermentation, yoghurt, probiotics

\section{Introduction}

The papaya fruit (carica papaya L.) is known for its food and nutraceutical value (Ali et al., 2011; Santana et al., 2019). It has considerable amounts of ascorbic acid (Vitamin C), carotenoids (precursors of vitamin A), tocopherol (vitamin E), potassium, calcium, magnesium, zinc, iron and manganese (Ali et al., 2012). As part of a healthy diet, it may reduce the risk for metabolic syndrome components such as hypertension, dyslipidemia and diabetes (Santana et al., 2019). 
Unfortunately, ripe papaya has a short shelf life of 2 to 3 days (Adetuyi et al., 2008). Incorporation of papaya pulp into yoghurt is one of the ways in which excess amounts of this fruit can be utilized to reduce its postharvest losses. Such fruit-containing yoghurts (fruit yoghurts) are gaining in popularity as a healthy alternative to high carbohydrate and high fat snacks (Fernandez et al., 2017). This is more so when fermentation is done by probiotic bacteria, which bestow various health benefits (Fernandez et al., 2017). Fruit yoghurts generally contain below $20 \%$ fruit, as higher proportions are associated with lower sensory attributes (Hossain, 2012; Roy et al., 2015). In this study, we investigated the potential of producing analogous probiotic products consisting primarily of papaya pulp and various amounts of milk. The products were fermented by a starter culture labeled by the manufacturer as being probiotic, and consisting of strains of Streptococcus thermophilus, Lactobacillus acidophilus and Bifidobacterium spp. Such products may contribute to reducing the postharvest loss of papaya, and improving human health.

\section{Materials and Methods \\ Materials}

Ripe papaya fruits of the red-orange colored accession were bought from the city hawkers market Nairobi, Kenya. Milk was obtained from J.K.U.AT dairy farm, while mixed starter culture ABT5 containing Streptococcus thermophilus, Lactobacillus acidophilus and Bifidobacterium spp. was bought from Chr. Hansen licensed suppliers in Nairobi, Kenya.

\section{Processing of yoghurt}

Yoghurt was processed according to the standard protocol used in the Dairy Workshop of the Department of Food Science and Technology, J. K. U. A. T. Briefly after, appropriate amounts of milk powder and sugar were added to milk. The mixture was stirred and pasteurized at $90^{\circ} \mathrm{C}$ for 30 minutes then cooled to $45^{\circ} \mathrm{C}$. This was followed by inoculation with the starter culture and incubation at $45^{\circ} \mathrm{C}$ for three hours. The yoghurt was finally kept at $10-15^{\circ} \mathrm{C}$ overnight prior to packaging using $250 \mathrm{~mL}$ plastic bottles.

\section{Preparation of papaya pulp}

Fully ripe papaya fruits were selected and washed in potable water. The peel and seeds were then removed followed by pulping using a blender.

\section{Optimization of papaya pulp pasteurization conditions}

The papaya pulp was divided into different portions and pasteurized at different temperature-time

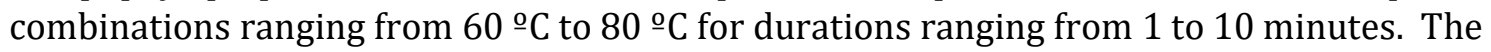
pasteurized samples were then subjected to determination of ascorbic acid content as well as yeasts and moulds. The best temperature-time combination was identified based on the ability to retain highest levels of vitamin $\mathrm{C}$ while effectively reducing plate counts of yeasts and moulds. Three independent determinations were done for all treatments prior to performing the relevant statistical analysis.

\section{Enumeration of yeasts and moulds}

Total yeast and mould counts were enumerated by the surface plate method using potato dextrose agar: (Hi Media Ltd., Mumbai, India) supplemented with 75 ppm chloramphenicol antibiotic using a sterile glass rod (Harrigan, 1998). Aliquots of $0.1 \mathrm{ml}$ of sample dilutions were spread on to the predried agar followed by incubation at $25^{\circ} \mathrm{C}$ for 5 days. Colony counts were done from plates containing 10-100 colonies and the colony forming units $(\mathrm{cfu} / \mathrm{mL})$ were determined as an average of these. 


\section{Fermentation of papaya pulp and papaya pulp-milk blends}

Pasteurized papaya and milk were mixed in different ratios ranging from 50-100\% papaya pulp, corresponding to $50-0 \%$ milk on weight basis. These formulations were inoculated with the starter culture and incubated at $45^{\circ} \mathrm{C}$, and fermentation was stopped upon attainment of $\mathrm{pH} 4.3$.

\section{Sensory analysis}

Sensory analysis of the different formulations was done by a team of 12 untrained panelists. Colour, taste, texture and overall acceptability were analyzed and scored using the nine point hedonic scale. [9-like extremely, 8- like very much, 7-like moderately, 6-like slightly, 5-neithrer like nor dislike, 4dislike slightly, 3-dislike moderately, 2-dislike very much, 1-dislike extremely].

\section{Physicochemical analysis}

Viscosity: Apparent viscosity was determined by using a Brookfield viscometer at room temperature. Readings were then converted to centipoise units (Daubert et al, 2010).

Total titratable acidity (TTA): Acidity was determined by sample titration with $0.1 \mathrm{~N} \mathrm{NaOH}$ using phenolphthalein as an indicator. Results were expressed as \% lactic acid. (AOAC, 1995). $\boldsymbol{p H}$ : The $\mathrm{pH}$ was measured using a calibrated $\mathrm{pH}$ meter (TOA pH Meter HM-7B, Tokyo, Japan). Ascorbic acid: Vitamin C content was determined by the 2, 6 dichlorophenol-indophenol titration method (AOAC 1990).

Vitamin B-complex: The B - vitamins were analyzed using a reversed-phase HPLC method, (Shimadzu model SCL-10A) using a column of inertsil ODS $5 \mu \mathrm{m} 4.6 \times 250 \mathrm{~mm}$ 5LI0101Z with 0.1 mol $/ \mathrm{L} \mathrm{KH}_{2} \mathrm{PO}_{4}$ (pH 7.0)-methanol, 90: 10 as the mobile phase (Ekinci and Kadakal, 2005)

\section{Proximate composition}

Moisture: Moisture content was determined by drying samples overnight at $105^{\circ} \mathrm{C}$ (AOAC 1990 ). The reduction in sample weight was taken to be the moisture content expressed as a percentage of the original weight of sample.

Protein: Total nitrogen was measured by micro-Kjeldahl method (AOAC 1990). Protein was calculated as $\mathrm{N} \times 6.25$.

Fat The soxhlet extraction method which gives intermittent extraction of oil with excess of organic solvent was used (AOAC, 1995). The weight of the extracted fat was expressed as a percentage of the original sample weight.

Fiber: Crude fiber content was determined according to the acid/alkali digestion method of Southgate (1976).

Ash: Ash content was determined by dry ashing of the samples for $24 \mathrm{~h}$ at $550^{\circ} \mathrm{C}$. (AOAC 1990 ). Carbohydrates: carbohydrates was determined by difference: \%Total carbohydrates $=100-$ [Total ash + fiber + fat + protein + moisture $]$

Statistical analysis: The experiments were performed in triplicates. Analysis of Variance (ANOVA) was performed using the Duncan's multiple-range test to compare treatment means. Significance was defined at $\mathrm{P}<0.05$. GENSTAT was used for this analysis.

\section{Results and discussion}

\section{Optimization of papaya pulp pasteurization conditions}

The condition of papaya pulp pasteurization was optimized based on ability to effectively destroy yeasts and moulds while retaining as much vitamin $C$ as possible. As shown in Table 1 , in the range of temperatures from $60-80{ }^{\circ} \mathrm{C}$, higher temperature was more effective in the destruction of yeasts and molds, but was associated with greater losses in ascorbic acid. The temperature-time combination of $80{ }^{\circ} \mathrm{C}$ and 4 minutes was selected as the optimum pasteurization condition. 
Nevertheless, with more sophisticated heating systems which can attain high temperatures within a short time, more precise, higher time and shorter temperature conditions with better nutrient retention might be possible.

Table 1. Final ascorbic acid content and yeast and mould counts after pasteurization at different time-temperature conditions

\begin{tabular}{ccc}
\hline Temperature-time $\left({ }^{\circ} \mathbf{C}-\right.$ Min $)$ & Vitamin C (mg/100 g) & Cfu/g(x10 $\left.\mathbf{~}^{\mathbf{1}}\right)$ \\
\hline $\mathbf{0}$ & $80.1 \pm 1.7^{\mathrm{d}}$ & $35 \pm 1.4^{\mathrm{c}}$ \\
$\mathbf{6 0 - 1}$ & $65.5 \pm 7.8^{\mathrm{c}}$ & $19 \pm 5.7^{\mathrm{b}}$ \\
$\mathbf{6 0 - 1 0}$ & $55.1 \pm 0.8^{\mathrm{b}}$ & $8.5 \pm 5.0^{\mathrm{a}}$ \\
$\mathbf{7 0 - 1}$ & $55.2 \pm 1.6^{\mathrm{b}}$ & $9 \pm 4.2^{\mathrm{a}}$ \\
$\mathbf{7 0 - 1 0}$ & $42.9 \pm 3.3^{\mathrm{a}}$ & $3.5 \pm 2.1^{\mathrm{a}}$ \\
$\mathbf{8 0 - 1}$ & $40.8 \pm 0.8^{\mathrm{a}}$ & $2.5 \pm 0.7^{\mathrm{a}}$ \\
$\mathbf{8 0 - 1 0}$ & $35.0 \pm 5.3^{\mathrm{a}}$ & ND \\
$\mathbf{8 0 - 2}$ & $39.8 \pm 1.8^{\mathrm{a}}$ & $0.5 \pm 0.5^{\mathrm{a}}$ \\
$\mathbf{8 0 - 4}$ & $38.6 \pm 0.9^{\mathrm{a}}$ & ND
\end{tabular}

NB: Means in columns with the same superscript are not significantly different $(P>0.05)$. ND-Not detected

Sensory acceptability of different fermented papaya-milk formulations

Sensory analysis was conducted on the various formulations, and, as shown in Table 2, there was a noticeable increase in scores of colour, taste, texture and overall acceptability with increasing papaya ratios up to $100 \%$ papaya. The sensory acceptability of the $100 \%$ papaya product was comparable to that of yoghurt (see Table 2 last 2 rows). 
Table 2. Sensory characteristics of fermented papaya (P)-milk (M) blends at different ratios

FORMULATION COLOUR TASTE
TEXTURE

OVERALL

ACCEPTABILITY

$\begin{array}{ccccc}\text { P:M, 40:60 } & 5.8 \pm 1.6^{\mathrm{a}} & 5.7 \pm 1.4^{\mathrm{a}} & 6.4 \pm 1.5^{\mathrm{a}} & 5.8 \pm 1.6^{\mathrm{ab}} \\ \text { P:M, 50:50 } & 6.4 \pm 1.2^{\mathrm{ab}} & 5.5 \pm 1.7^{\mathrm{a}} & 6.2 \pm 1.7^{\mathrm{a}} & 5.6 \pm 1.9^{\mathrm{a}} \\ \text { P:M, 60:40 } & 6.5 \pm 1.5^{\mathrm{ab}} & 5.3 \pm 1.6^{\mathrm{a}} & 5.9 \pm 1.6^{\mathrm{a}} & 5.6 \pm 1.6^{\mathrm{a}} \\ \text { P:M, 70:30 } & 6.6 \pm 1.7^{\mathrm{ab}} & 5.5 \pm 1.4^{\mathrm{a}} & 5.9 \pm 1.1^{\mathrm{a}} & 6.0 \pm 1.4^{\mathrm{abc}} \\ \text { P:M, 80:20 } & 7.3 \pm 1.9^{\mathrm{bc}} & 7.0 \pm 1.6^{\mathrm{b}} & 6.9 \pm 1.8^{\mathrm{a}} & 6.9 \pm 1.9^{\mathrm{c}} \\ \text { P:M, 90:10 } & 7.1 \pm 1.7^{\mathrm{bc}} & 7.0 \pm 1.5^{\mathrm{b}} & 6.7 \pm 1.7^{\mathrm{a}} & 7.0 \pm 1.3^{\mathrm{c}} \\ \text { P:M,100:0 } & 7.6 \pm 1.3^{\mathrm{c}} & 7.8 \pm 1.6^{\mathrm{c}} & 7.9 \pm 1.4^{\mathrm{b}} & 7.6 \pm 1.2^{\mathrm{d}} \\ \text { P:M, 0:100 (control) } & 7.0 \pm 1.5^{\mathrm{bc}} & 7.8 \pm 0.7^{\mathrm{c}} & 8.0 \pm 0.9^{\mathrm{b}} & 7.7 \pm 0.8^{\mathrm{d}}\end{array}$

NB: Means in columns with the same superscript are not significantly different $(\mathrm{P}>0.05)$ scale [1dislike extremely, 9-like extremely]

Based on the superior sensory acceptability of the papaya milk blends containing above $80 \%$ papaya pulp, the rest of the studies were performed on the 80-20, 90-10, and 100-0 fermented papaya-milk blends, with yoghurt as the control.

\section{Changes in pH during fermentation}

During fermentation by lactic acid bacteria, the $\mathrm{pH}$ of the product decreases as the amount of lactic acid in the product increases. As shown in Table 2, the initial $\mathrm{pH}$ of the samples ranged from 6.7 (100\% milk) to 5.7 (100\% papaya pulp), and in all cases the pH dropped to $\leq 4.4$ in 4 hours. Commercial yoghurts generally have a pH of less than 4.5 , which is associated with the taste of yoghurt and also helps in preventing growth of undesirable bacteria in the product (Tavakoli et al., 2019).

Table 3. Changes in pH during fermentation of papaya yoghurt formulations

\begin{tabular}{llllll}
\hline PRODUCT & \multicolumn{5}{c}{ pH } \\
\hline Time (Hours) & $\mathbf{0}$ & $\mathbf{2}$ & $\mathbf{4}$ & $\mathbf{6}$ & $\mathbf{8}$ \\
\hline P:M, 0:100 & $6.7 \pm 0.2^{\mathrm{c}}$ & $4.9 \pm 0.1^{\mathrm{b}}$ & $4.3 \pm 0.2^{\mathrm{a}}$ & $4.0 \pm 0.1^{\mathrm{a}}$ & $4.0 \pm 0.1^{\mathrm{a}}$ \\
P:M, 80:20 & $6.5 \pm 0.2^{\mathrm{b}}$ & $4.8 \pm 0.1^{\mathrm{b}}$ & $4.3 \pm 0.1^{\mathrm{a}}$ & $4.2 \pm 0.1^{\mathrm{a}}$ & $4.0 \pm 0.1^{\mathrm{a}}$ \\
P:M, 90:10 & $6.0 \pm 0.3^{\mathrm{d}}$ & $4.7 \pm 0.1^{\mathrm{c}}$ & $4.4 \pm 0.1^{\mathrm{bc}}$ & $4.2 \pm 0.1^{\mathrm{ab}}$ & $4.0 \pm 0.1^{\mathrm{a}}$ \\
P:M, 100:0 & $5.7 \pm 0.1^{\mathrm{c}}$ & $4.8 \pm 0.2^{\mathrm{b}}$ & $4.3 \pm 0.2^{\mathrm{a}}$ & $4.0 \pm 0.1^{\mathrm{a}}$ & $4.0 \pm 0.1^{\mathrm{a}}$ \\
\hline
\end{tabular}

NB: Means in rows with the same superscript are not significantly different $(P>0.05)$

\section{Proximate composition of the fermented products}

As shown in Table 3, yoghurt (P:M, 0:100) had higher protein and fat but less fibre and carbohydrates than the products containing papaya pulp, while all products had similar ash 
contents. The similar ash between papaya and milk indicates that they have similar amounts of minerals. The most abundant mineral in papaya is potassium, which may contribute to its blood pressure lowering effects (Santana et al., 2019).

Table 4. Proximate composition (wet basis) of different fermented papaya (P)-milk (M) blends

\begin{tabular}{|c|c|c|c|c|c|c|}
\hline \multirow[t]{2}{*}{ PRODUCT } & \multicolumn{6}{|c|}{ PARAMETER } \\
\hline & MOISTURE & PROTEIN & FAT & ASH & FIBER & CHO \\
\hline \multicolumn{7}{|c|}{$(\mathrm{g} / 100 \mathrm{~g})$} \\
\hline P:M, 0:100 & $85.1 \pm 0.1 b^{a}$ & $4.3 \pm 0.1^{\mathrm{d}}$ & $2.3 \pm 0.2^{\mathrm{c}}$ & $0.5 \pm 0.0^{\mathrm{a}}$ & ND & $7.9 \pm 0.2^{\mathrm{a}}$ \\
\hline P:M, 80:20 & $86.3 \pm 0.1^{a}$ & $1.5 \pm 0.0^{c}$ & $0.8 \pm 0.0^{b}$ & $0.5 \pm 0.0^{a}$ & $0.6 \pm 0.0^{\mathrm{b}}$ & $10.4 \pm 0.0^{b}$ \\
\hline$P: M, 90: 10$ & $86.2 \pm 0.1^{\mathrm{a}}$ & $1.2 \pm 0.0^{\mathrm{b}}$ & $0.6 \pm 0.0^{\mathrm{ab}}$ & $0.5 \pm 0.0^{\mathrm{a}}$ & $0.7 \pm 0.0^{c}$ & $10.9 \pm 0.0^{c}$ \\
\hline$P: M, 100: 0$ & $86.2 \pm 0.1^{\mathrm{a}}$ & $0.9 \pm 0.0^{\mathrm{a}}$ & $0.3 \pm 0.0^{\mathrm{a}}$ & $0.5 \pm 0.0^{a}$ & $0.8 \pm 0.1^{b}$ & $11.4 \pm 0.0^{\mathrm{d}}$ \\
\hline
\end{tabular}

NB: means in columns with the same superscript are not significantly different $(P>0.05), N D-N o t$ Detected, CHO-Carbohydrates.

\section{Changes in physico-chemical characteristics during storage}

Physico-chemical characteristics such as $\mathrm{pH}$ and viscosity influence sensory characteristics, and their changes during storage influence the keeping quality of products. As shown in Table 4, there were insignificant changes in $\mathrm{pH}$, titratable acidity and viscosity in both yoghurt and papayacontaining fermented products during three weeks of storage. 
Table 5. Physico-chemical analysis of papaya-based yoghurts during storage

\begin{tabular}{llll}
\hline PRODUCT & WEEK 1 & WEEK 2 & WEEK 3 \\
\hline pH & & \\
\cline { 2 - 4 } P:M, 0:100 & $4.3 \pm 0.2^{\mathrm{a}}$ & $4.2 \pm 0.4^{\mathrm{a}}$ & $4.1 \pm 0.4^{\mathrm{a}}$ \\
P:M, 80:20 & $4.4 \pm 0.2^{\mathrm{a}}$ & $4.2 \pm 0.2^{\mathrm{a}}$ & $4.1 \pm 0.3^{\mathrm{a}}$ \\
P:M, 90:10 & $4.4 \pm 0.1^{\mathrm{a}}$ & $4.2 \pm 0.2^{\mathrm{a}}$ & $4.2 \pm 0.3^{\mathrm{a}}$ \\
\hline \%: Total titratable acidity (TTA) & & $1.4 \pm 1.3^{\mathrm{a}}$ \\
P:M, 0:100 & $1.1 \pm 0.9^{\mathrm{a}}$ & $1.2 \pm 1.0^{\mathrm{a}}$ & $1.3 \pm 1.6^{\mathrm{a}}$ \\
P:M, 80:20 & $1.0 \pm 0.9^{\mathrm{a}}$ & $1.1 \pm 1.9^{\mathrm{a}}$ & $1.2 \pm 0.6^{\mathrm{a}}$ \\
P:M, 90:10 & $0.8 \pm 0.4^{\mathrm{a}}$ & $1.0 \pm 0.4^{\mathrm{a}}$ & \\
\hline VISC0SITY (Cp) & & & $6650 \pm 353.6^{\mathrm{a}}$ \\
P:M, 0:100 & $6750 \pm 1474.9^{\mathrm{a}}$ & $6700 \pm 1060.7^{\mathrm{a}}$ & $12000 \pm 711.2^{\mathrm{a}}$ \\
P:M, 80:20 & $18250 \pm 2474.9^{\mathrm{b}}$ & $15000 \pm 707.1^{\mathrm{ab}}$ & $18250 \pm 2010.4^{\mathrm{a}}$ \\
P:M, 90:10 & $19870 \pm 3182.0^{\mathrm{a}}$ & $19275 \pm 1601.4^{\mathrm{a}}$ & \\
\hline
\end{tabular}

NB: Means in rows with the same superscript are not significantly different $(P>0.05)$

\section{Changes in sensory characteristics during storage}

As shown in Table 6, there were insignificant $(P>0.05)$ changes in the sensory scores for colour, texture and overall acceptability of the products at the end of three weeks. On the other hand, the decline in scores for taste was significant. For example, at the end of three weeks, the taste score of the 80:20 papaya-milk formulation was the lowest at 6.4, showing that it was only slightly liked as compared to week 1 when it was liked moderately. Thus, based on the changing taste, it was considered that the products are best for consumption within three weeks of preparation. 
Table 6. Sensory evaluation of papaya-based yoghurts during storage

\begin{tabular}{|c|c|c|c|}
\hline PRODUCT & WEEK 1 & WEEK 2 & WEEK 3 \\
\hline \multicolumn{4}{|c|}{ COLOUR } \\
\hline P:M, 0:100 & $7.8 \pm 1.5^{\mathrm{a}}$ & $7.8 \pm 1.3^{\mathrm{a}}$ & $7.6 \pm 1.8^{a}$ \\
\hline P:M, 80:20 & $7.7 \pm 0.8^{a}$ & $7.6 \pm 0.8^{a}$ & $7.6 \pm 1.2^{\mathrm{a}}$ \\
\hline$P: M, 90: 10$ & $7.8 \pm 0.8^{\mathrm{a}}$ & $7.8 \pm 1.8^{\mathrm{a}}$ & $7.7 \pm 0.6^{\mathrm{a}}$ \\
\hline \multicolumn{4}{|c|}{ TASTE } \\
\hline$P: M, 0: 100$ & $8.1 \pm 0.4^{b}$ & $7.9 \pm 1.1^{\mathrm{ab}}$ & $7.6 \pm 0.9^{a}$ \\
\hline$P: M, 80: 20$ & $7.1 \pm 0.6^{b}$ & $6.8 \pm 1.3^{\mathrm{ab}}$ & $6.4 \pm 0.8^{a}$ \\
\hline$P: M, 90: 10$ & $7.6 \pm 0.9 \mathrm{~b}$ & $7.4 \pm 0.9 \mathrm{~b}$ & $7.0 \pm 1.3^{\mathrm{a}}$ \\
\hline \multicolumn{4}{|c|}{ TEXTURE } \\
\hline P:M, 0:100 & $8.0 \pm 0.8^{a}$ & $7.8 \pm 0.9^{a}$ & $7.7 \pm 1.2^{\mathrm{a}}$ \\
\hline$P: M, 80: 20$ & $7.5 \pm 1.1^{\mathrm{a}}$ & $7.3 \pm 1.7^{\mathrm{a}}$ & $7.1 \pm 0.5^{\mathrm{a}}$ \\
\hline$P: M, 90: 10$ & $7.5 \pm 0.8^{\mathrm{a}}$ & $6.9 \pm 1.6^{\mathrm{a}}$ & $6.8 \pm 1.6^{a}$ \\
\hline \multicolumn{4}{|c|}{ OVERALL ACCEPTABILITY } \\
\hline P:M, 0:100 & $8.0 \pm 0.6^{\mathrm{a}}$ & $7.8 \pm 1.2^{\mathrm{a}}$ & $7.6 \pm 0.3^{a}$ \\
\hline$P: M, 80: 20$ & $7.4 \pm 1.3^{\mathrm{a}}$ & $7.1 \pm 1.8^{a}$ & $6.8 \pm 0.9 \mathrm{a}$ \\
\hline P:M, 90:10 & $7.5 \pm 1.2^{\mathrm{a}}$ & $7.3 \pm 1.1^{\mathrm{a}}$ & $7.1 \pm 1.2^{\mathrm{a}}$ \\
\hline
\end{tabular}

$N B$ : Means in rows with the same superscript are not significantly different $(P>0.05)$, [1-dislike extremely, 9-like extremely]

\section{Changes in LAB (lactic acid bacteria) during storage}

For a product to be considered probiotic, it should contain at least $10^{6} \mathrm{Cfu} / \mathrm{g}$ (Yerlikaya, 2014). As shown in Table 7, the products attained 4.5-5.8 $\times 10^{6} \mathrm{cfu} / \mathrm{g}$ during the fermentation, with the 90:10, P:M formulation attaining the highest bacterial population, and yoghurt attaining the lowest. Although there was a significant decline in the numbers of bacteria during storage for three weeks, the numbers still met the $10^{6} \mathrm{cfu} / \mathrm{g}$ threshold. Thus, these products can be considered as a good carrier of the probiotic bacteria.

Table 7. Changes in LAB counts of papaya yoghurt formulations inoculated with probiotic culture during storage
PRODUCT
Cfu/g (106)

\begin{tabular}{ccc} 
& Week 0 & Week 3 \\
\hline P:M, 0:100 & $4.5 \pm 0.8^{\mathrm{c}}$ & $2.2 \pm 0.2^{\mathrm{a}}$ \\
P:M, 80:20 & $5.0 \pm 1.7^{\mathrm{c}}$ & $3.3 \pm 1.3^{\mathrm{a}}$ \\
P:M, 90:10 & $5.8 \pm 0.2^{\mathrm{c}}$ & $3.5 \pm 1.5^{\mathrm{a}}$ \\
P:M, 100:0 & $4.8 \pm 0.6^{\mathrm{c}}$ & $2.6 \pm 1.1^{\mathrm{a}}$ \\
\hline
\end{tabular}




\section{Changes in vitamins during fermentation and storage}

Both papaya and milk are good sources of vitamins, and these are known to be affected differently during fermentation and storage (Anino et al., 2019). In this study, there were significant increases in riboflavin, thiamine and folic acid (Tables 8-10), and decreases in pyridoxine, niacin and ascorbic acid (Tables 8-13) during fermentation. Pyridoxine was not detected after fermentation, signifying its depletion. From Tables 7-11, there were slight reductions in most of the vitamins during storage. Reduction in vitamin $\mathrm{C}$ during refrigerated storage of milk has been previously reported (Romeu-Nadal et al., 2008), although the reason for this in not well known.

Table 8. Changes in riboflavin during fermentation and storage of papaya-yoghurt formulations

\begin{tabular}{llllll}
\hline PRODUCT & BB.F & AA.F & WEEK 1 & WEEK 2 & WEEK 3 \\
\cline { 2 - 6 } & \multicolumn{5}{c}{ (mg/100 g) } \\
\hline P:M, 0:100 & $0.018 \pm 0.001^{\mathrm{a}}$ & $0.022 \pm 0.001^{\mathrm{b}}$ & $0.018 \pm 0.001^{\mathrm{a}}$ & $0.018 \pm 0.001^{\mathrm{a}}$ & $0.017 \pm 0.001^{\mathrm{a}}$ \\
& & & & & \\
P:M, 80:20 & $0.031 \pm 0.001^{\mathrm{a}}$ & $0.035 \pm 0.001^{\mathrm{c}}$ & $0.034 \pm 0.002^{\mathrm{bc}}$ & $0.034 \pm 0.001^{\mathrm{bc}}$ & $0.032 \pm 0.001^{\mathrm{ab}}$ \\
P:M, 90:10 & $0.032 \pm 0.001^{\mathrm{a}}$ & $0.036 \pm 0.001^{\mathrm{b}}$ & $0.034 \pm 0.0^{\mathrm{ab}}$ & $0.036 \pm 0.0^{\mathrm{b}}$ & $0.034 \pm 0.001^{\mathrm{ab}}$ \\
P:M, 100:0 & $0.032 \pm 0.001^{\mathrm{a}}$ & $0.04 \pm 0.001^{\mathrm{b}}$ & $0.04 \pm 0.0^{\mathrm{b}}$ & $0.039 \pm 0.001^{\mathrm{b}}$ & $0.038 \pm 0.002^{\mathrm{b}}$
\end{tabular}

NB: Means in rows with the same superscript are not significantly different $(P>0.05) .{ }^{B}$ B.F-Before fermentation, ${ }^{A}$ A.F-After fermentation.

Table 9. Changes in thiamine during fermentation and storage of papaya-yoghurt formulations

\begin{tabular}{llllll}
\hline PRODUCT & BB.F & AA.F & WEEK 1 & WEEK 2 & WEEK 3 \\
\cline { 2 - 6 } (mg/100 g) & & & & \\
\hline P:M, 0:100 & $0.041 \pm 0.001^{\mathrm{a}}$ & $0.053 \pm 0.002^{\mathrm{d}}$ & $0.051 \pm 0.001^{\mathrm{c}}$ & $0.047 \pm 0.001^{\mathrm{b}}$ & $0.048 \pm 0.001^{\mathrm{b}}$ \\
P:M, 80:20 & $0.028 \pm 0.001^{\mathrm{ab}}$ & $0.029 \pm 0.002^{\mathrm{b}}$ & $0.029 \pm 0.001^{\mathrm{b}}$ & $0.027 \pm 0.001^{\mathrm{a}}$ & $0.027 \pm 0.001^{\mathrm{a}}$ \\
P:M, 90:10 & $0.026 \pm 0.001^{\mathrm{abc}}$ & $0.027 \pm 0.001^{\mathrm{c}}$ & $0.026 \pm 0.001^{\mathrm{bc}}$ & $0.024 \pm 0.001^{\mathrm{ab}}$ & $0.023 \pm 0.001^{\mathrm{a}}$ \\
P:M, 100:0 & $0.025 \pm 0.001^{\mathrm{a}}$ & $0.033 \pm 0.001^{\mathrm{c}}$ & $0.033 \pm 0.001^{\mathrm{c}}$ & $0.032 \pm 0.001^{\mathrm{bc}}$ & $0.031 \pm 0^{\mathrm{b}}$ \\
\hline
\end{tabular}

NB: Means in rows with the same superscript are not significantly different $(P>0.05) .{ }^{B} B . F-B e f o r e$ fermentation, ${ }^{A}$ A.F-After fermentation. 
Table 10. Changes in folic acid during fermentation and storage of papaya yoghurt formulations

\begin{tabular}{llllll}
\hline PRODUCT & BB.F & AA.F & WEEK 1 & WEEK 2 & WEEK 3 \\
\cline { 2 - 5 }$(\mathbf{m g} / 100 \mathrm{~g})$ & & & & \\
\hline & & & & \\
\hline P:M, 0:100 & $0.001 \pm 0^{\mathrm{a}}$ & $0.014 \pm 0.001^{\mathrm{b}}$ & $0.015 \pm 0.001^{\mathrm{b}}$ & $0.014 \pm 0.001^{\mathrm{b}}$ & $0.013 \pm 0.001^{\mathrm{b}}$ \\
P:M, 80:20 & $0.019 \pm 0^{\mathrm{a}}$ & $0.028 \pm 0.001^{\mathrm{c}}$ & $0.028 \pm 0.0^{\mathrm{c}}$ & $0.026 \pm 0.0^{\mathrm{cb}}$ & $0.025 \pm 0.001^{\mathrm{b}}$ \\
P:M, 90:10 & $0.020 \pm 0^{\mathrm{a}}$ & $0.023 \pm 0.001^{\mathrm{b}}$ & $0.022 \pm 0.001^{\mathrm{ab}}$ & $0.022 \pm 0.0^{\mathrm{ab}}$ & $0.021 \pm 0.001^{\mathrm{a}}$ \\
P:M, 100:0 & $0.022 \pm 0.001^{\mathrm{a}}$ & $0.029 \pm 0.002^{\mathrm{b}}$ & $0.029 \pm 0.001^{\mathrm{b}}$ & $0.028 \pm 0.001^{\mathrm{b}}$ & $0.026 \pm 0.002^{\mathrm{b}}$ \\
\hline
\end{tabular}

NB: Means in rows with the same superscript are not significantly different $(P>0.05) .{ }^{B}$ B.FBefore fermentation, ${ }^{A}$ A.F-After fermentation.

Table 11. Changes in niacin during fermentation and storage of papaya-yoghurt formulations

\begin{tabular}{cccccc}
\hline PRODUCT & BB.F & AA.F & WEEK 1 & WEEK 2 & WEEK 3 \\
\cline { 2 - 6 } & \multicolumn{5}{c}{$\mathbf{( m g / 1 0 0 ~ g ) ~}$} \\
\hline P:M, 0:100 & $0.392 \pm 0.001^{\mathrm{b}}$ & $0.013 \pm 0.001^{\mathrm{a}}$ & $0.012 \pm 0.001^{\mathrm{a}}$ & $0.01 \pm 0.00^{\mathrm{a}}$ & $0.010 \pm 0.0^{\mathrm{a}}$ \\
& & & & \\
P:M, 80:20 & $0.480 \pm 0.001^{\mathrm{b}}$ & $0.029 \pm 0^{\mathrm{a}}$ & $0.026 \pm 0.001^{\mathrm{a}}$ & $0.0265 \pm 0.0^{\mathrm{a}}$ & $0.025 \pm 0.001^{\mathrm{a}}$ \\
P:M, 90:10 & $0.490 \pm 0.001^{\mathrm{b}}$ & $0.022 \pm 0.001^{\mathrm{a}}$ & $0.019 \pm 0.001^{\mathrm{a}}$ & $0.020 \pm 0.0^{\mathrm{a}}$ & $0.018 \pm 0.0^{\mathrm{a}}$ \\
& & & & & \\
P:M, 100:0 & $0.500 \pm 0.014^{\mathrm{c}}$ & $0.025 \pm 0.001^{\mathrm{b}}$ & $0.021 \pm 0.002^{\mathrm{a}}$ & $0.018 \pm 0.001^{\mathrm{a}}$ & $0.018 \pm 0.002^{\mathrm{a}}$
\end{tabular}

NB: Means in rows with the same superscript are not significantly different $(P>0.05) .{ }^{B} B . F-B e f o r e$ fermentation, ${ }^{A}$ A.F-After fermentation. 
Table 12. Changes in pyridoxine during fermentation and storage of papaya-yoghurt formulations

\begin{tabular}{llllll}
\hline PRODUCT & BB.F & AA.F & WEEK 1 & WEEK 2 & WEEK 3 \\
\cline { 2 - 6 } & \multicolumn{2}{c}{$(\mathbf{m g} / \mathbf{1 0 0} \mathbf{g})$} & & \\
\hline P:M, 0:100 & $0.043 \pm 0.001$ & ND & ND & ND & ND \\
P:M. 80:20 & $0.027 \pm 0.001$ & ND & ND & ND & ND \\
P:M, 90:10 & $0.026 \pm 0.001$ & ND & ND & ND & ND \\
P:M, 100:0 & $0.022 \pm 0.001$ & ND & ND & ND & ND \\
\hline
\end{tabular}

NB: Means in rows with the same superscript are not significantly different $(P>0.05) .{ }^{B} B . F-B e f o r e$ fermentation, ${ }^{A}$ A.F-After fermentation, $N D$ - Not Detected.

Table 13. Changes in ascorbic acid during fermentation and storage of papaya-yoghurt Formulations

\begin{tabular}{cccccc}
\hline PRODUCT & BB.F & AA.F & WEEK 1 & WEEK 2 & WEEK 3 \\
\cline { 2 - 6 } & \multicolumn{5}{c}{ (mg/100 g) } \\
\hline P:M, 0:100 & $0.01 \pm 0.001$ & ND & ND & ND & ND \\
P:M, 80:20 & $26.96 \pm 0.78^{c}$ & $21.97 \pm 0.61^{\mathrm{b}}$ & $19.85 \pm 0.62^{\mathrm{a}}$ & $18.81 \pm 0.23^{\mathrm{a}}$ & $18.55 \pm 0.49^{\mathrm{a}}$ \\
P:M, 90:10 & $29.39 \pm 0.412^{\mathrm{b}}$ & $23.66 \pm 0.63^{\mathrm{a}}$ & $21.65 \pm 1.767^{\mathrm{a}}$ & $21.34 \pm 0.622^{\mathrm{a}}$ & $21.26 \pm 0.495^{\mathrm{a}}$ \\
P:M, 100:0 & $33.55 \pm 0.806^{\mathrm{c}}$ & $29.35 \pm 0.636^{\mathrm{b}}$ & $27.89 \pm 0.007^{\mathrm{a}}$ & $27.09 \pm 0.29^{\mathrm{a}}$ & $26.59 \pm 0.417^{\mathrm{a}}$ \\
\hline
\end{tabular}

NB: Means in rows with the same superscript are not significantly different $(P>0.05) .{ }^{B} B . F-B e f o r e$ fermentation, ${ }^{A}$ A.F-After fermentation, $N D$ - Not Detected 


\section{References}

Adetuyi, F.O., Akinadewo, L. T., Omosuli, S. V. \& Lola, A. (2008). Antinutrient and antioxidant quality of waxed and unwaxed pawpaw (Carica papaya) fruit stored at different temperatures. African Journal of Biotechnology 7, 2920-2924.

Ali, A., Devarajan, S., Waly, M., Essa, M. M., \& Rahman, M. S. (2012). Nutritional and medicinal value of papaya (Carica papaya L.). In M. E. Mustafa, A. Manickasavagan \& E. Sukumar (Eds.). Natural products and bioactive compounds in disease prevention (pp. 34-42). Nova Science Pub Inc;

Anino, C., Onyango, A., Imathiu, S., \& Maina, J. (2019). Effect of lactic acid bacteria starter cultures on vitamin and oligosaccharide composition of milk extracted from three common bean (L) varieties. Journal of Food Research 8, 103-110. doi:10.5539/jfr.v8n3p103

AOAC (1990). Official Methods of Analysis (15th edition), Association of Official Analytical Chemists, Washington, D.C, USA.

AOAC (1995). Official Methods of Analysis (15th edition), Association of Official Analytical Chemists, Washington, D.C, USA.

Daubert, C. R., \& Farkas, B. E. (2010). Viscosity measurement using a brookfield viscometer. In S. Suzanne Nielsen (Ed.), Food Analysis Laboratory Manual (pp. 165-169). Springer, Boston, MA.

Fernandez, M. A., \& Marette, A. (2017). Potential health benefits of combining yogurt and fruits based on their probiotic and prebiotic properties. Advances in Nutrition 8(1), 155S-164S. doi: 10.3945/an.115.011114.

Harrigan, W. F. (1998). Laboratory methods on food microbiology. (3rd Ed.). Academic press Ltd, San Diego. p 163-165.

Hossain, M. N., Fakruddin, M., \& Islam, M. N. (2012). Quality comparison and acceptability of yoghurt with different fruit juices. Journal of Food Processing \& Technology 3(8), 1-5. doi: 10.4172/2157-7110.1000171

Romeu-Nadal, M., Castellote, A. I., \& López-Sabater, M. C. (2008). Effect of cold storage on vitamins $\mathrm{C}$ and $\mathrm{E}$ and fatty acids in human milk. Food Chemistry 106(1), 65-70. doi:10.1016/j.foodchem.2007.05.046.

Roy, D. K. D., Saha, T., Akter, M., Hosain, M., Khatun, H., \& Roy, M. C. (2015). Quality evaluation of yogurt supplemented with fruit pulp (banana, papaya, and water melon). International Journal of Nutrition and Food Sciences 4(6), 695-699. doi: 10.11648/j.ijnfs.20150406.25.

Santana, L. F., Inada, A. C., Espirito Santo, B. L. S. D., Filiú, W. F., Pott, A., Alves, F. M. \& Hiane, P. A. (2019). Nutraceutical potential of Carica papaya in metabolic syndrome. Nutrients 11(7), 1608. https://doi.org/10.3390/nu11071608.

Tavakoli, M., Najafi, M. B. H., \& Mohebbi, M. (2019). Effect of the milk fat content and starter culture selection on proteolysis and antioxidant activity of probiotic yogurt. Heliyon 5(2), e01204. https://doi.org/10.1016/j.heliyon.2019.e01204. 